\title{
US. WAGE INEQUALITY AND LOW-WAGE IMPORT COMPETITION
}

\author{
David Rigby $^{2}$, Thomas Kemeny ${ }^{3}$ and Abigail Cooke ${ }^{2}$ \\ Forthcoming 2015 in Tijdschrift voor Economische en Sociale Geografie
}

1 This research was funded by the National Science Foundation, grant number 0961735

2 Department of Geography, UCLA

3 Department of Geography and Environment, University of Southampton 


\title{
US. WAGE INEQUALITY AND LOW-WAGE IMPORT COMPETITION
}

\begin{abstract}
This article examines the impact of import competition from low-wage countries (LWCs) on wages and wage inequality in the U.S. over the period 1972-2006. During the 1990s, studies appeared to settle this issue, finding that technology, not trade, accounted for the bulk of rising inequality. This paper revisits the link between trade and wages, motivated by two changes in the structure of trade. First, trade today is shaped as much by the exchange of components and tasks as finished goods. Second, import volumes from LWCs into advanced economies like the U.S. have risen dramatically since the early 1990s. The paper pays special attention to the timing of trade impacts. Consistent with prior work, it shows that technological change is the primary driver of inequality before 1990 . However, after 1990 wage inequality growth is chiefly a function of rising import competition from low-wage economies. To account for the growing fragmentation of production within economic sectors, we explore trade impacts using a panel model where the focus in on within- rather than between-industry shifts in inequality. Lags of key variables are used as instruments, and our results appear robust to broad concerns with endogeneity and to different measures of skill-biased technological change.
\end{abstract}




\section{U.S. Wage Inequality and Low-Wage Import Competition}

\section{Introduction}

Since the late-1970s wage inequality, defined here as the wages of skilled workers relative to the wages of unskilled workers, has risen sharply in the United States. Several factors have been offered to explain the growing wage gap including industrial restructuring and the decline of unions (Bluestone and Harrison, 1982; Thurow, 1984); immigration (Borjas et al., 1992); the introduction of computers and related technology into the workforce (Haskell and Slaughter, 1998); and international trade. Following the work of Levy and Murnane (1992) and Borjas et al. (1992), attention converged rapidly on the relative roles of skill-biased technological change and trade as the main suspects. Early efforts to explain the growth of inequality with rising import competition found little support (Lawrence and Slaughter, 1993; Richardson, 1995). Skill-biased technological change was left as the primary determinant of growing wage inequality through the 1980s (Haskell and Slaughter, 1998).

Over the last few years there have been repeated calls to re-examine the trade-wage inequality relationship (Blinder, 2006; Bivens, 2007; Krugman, 2008). These calls are motivated by two broad concerns. First, the structure of trade has been transformed from a situation dominated by the exchange of finished goods, to one in which countries produce and trade components, tasks or activities variously bundled along international supply chains (Gereffi, 1994; Feenstra and Hanson, 1996; Coe et al., 2004; Baldwin, 2006; Grossman and RossiHansberg, 2006, 2008). Second, the volume of trade involving low-wage economies, especially China, has risen dramatically, especially since the early-1990s. The first of these factors suggests that the early attempts to link trade and inequality in cross-sectional models were looking in the wrong place: rather than examining reallocation of resources from "low tech" to "high tech" 
sectors, they should have been analyzing changes in the structure of production within industries (Feenstra and Hanson, 2001; Helpman et al., 2010). The second concern demands that we separate the influence of trade with low-wage economies from the impacts of trade overall (Bernard et al., 2006; Autor et al., 2011).

We respond to these concerns in this paper, focusing on U.S. import competition from low-wage countries (LWCs) and its impact on wages and wage inequality. We pay special attention to the timing of trade impacts, showing that before 1990 technological change was more important to the growth of wage inequality than was trade with LWCs. In part, this is due to the relatively small volume of LWC imports into the U.S. at this time. Post-1990, import competition from low-wage economies has a positive and significant impact on wage inequality, while the influence of technological change is negligible. To account for the growing fragmentation of production within economic sectors, we explore these impacts using a panel model that focuses attention on shifts in wage inequality within industries rather than between them. Lags of key variables are used as instruments, and our results appear robust to broad concerns with endogeneity and to different measures of technological change.

The paper is organized in four sections that follow. Section 2 provides some background information on shifts in U.S. import competition and past research linking trade and wage inequality. In Section 3, we outline data sources and our general model specification. Results are discussed in Section 4. Section 5 summarizes the main findings.

\section{Background}

As in most countries around the world, trade is becoming increasingly important to the U.S. economy. From 1972 to 2007, imports as a share of U.S. GDP climbed from 5.3\% to 
approximately $15.5 \%$. Over this same period the share of imports to the U.S. originating in lowwage countries ${ }^{1}$ has grown faster still, with most of this growth concentrated in the period since 1990. Figure 1 illustrates the growth of manufactured imports to the U.S. from these low-wage economies, and from the rest of the world in total. ${ }^{2}$ We focus on manufactured imports throughout this paper because of the lack of production data for other parts of the U.S. economy.

[FIGURE 1 ABOUT HERE]

The value of total U.S. manufactured imports expanded from \$185 billion in 1972 to $\$ 1280$ billion by 2006 (in constant, year-2000 dollars). As Figure 1 shows, the share of U.S. manufactured imports originating in low-wage countries has increased, especially since the end of the 1980s. Indeed, between 1972 and 2006, LWC manufactured imports to the United States increased at an annual average compound growth rate of $10.6 \%$, compared with a growth rate of $5.7 \%$ for manufactured imports in total. In 1972, the LWC share of total manufactured imports to the U.S. stood at 7.5\%. This share increased to $15.9 \%$ in 1990 and to $40.4 \%$ in 2006 .

\section{[FIGURE 2A ABOUT HERE]}

In the United States, the last few decades have been marked by a dramatic swing in the geographic origin of imports, a remapping of trade, at least in relative terms, away from other advanced industrialized countries towards lower and middle income developing nations. Figures $2 \mathrm{a}$ and $2 \mathrm{~b}$ illustrate these shifts, highlighting the sources of U.S. imports from low-wage

\footnotetext{
${ }^{1}$ Low-wage countries are identified using World Bank data for the year 1988, the mid-point of our period of investigation. Low-wage economies comprise those countries the World Bank defines as low income and lowermiddle income.

${ }^{2}$ Manufactured imports accounted for approximately $83 \%$ of all U.S. imports in 2006.
} 
countries and from industrialized nations (medium- and high-wage countries), and revealing how the volume of trade flows from different regions has changed over time.

Figure 2a shows the rapid growth of U.S. imports from Mexico and LWCs in the East Asia and Pacific region over the last few decades. In 1972, these two regions combined accounted for $51 \%$ of U.S. imports from developing economies. By 2006, the LWC import share of these two regions was $87 \%$. Figure $2 \mathrm{~b}$ shows the origins of U.S. imports from industrialized nations. The shares of world regions in non-LWC exports to the United States have remained relatively stable, dominated by flows from Europe and Central Asia, from the East Asia and Pacific region, and from Canada. Between 1972 and 1990, the East Asia and Pacific region recorded the largest growth in exports to the United States, while European and Central Asian exports to the U.S. grew most rapidly after 1990.

\section{[FIGURE 2B ABOUT HERE]}

China alone is responsible for $30 \%$ of the growth in U.S. manufactured imports since 1990 (and thereby, a large portion of the increase in LWC imports from the East Asia and Pacific region in Figure 2a). The marked rise in imported manufactured goods from China, not only by the United States but a broad range of economies, has prompted examination of the nature of these products. Particular attention has been focused on their level of technological sophistication, and potential labor market impacts across developed economies (Rodrik, 2006; Koopman et al., 2008; Schott, 2008). Of the labor market impacts of trade, wage inequality has received by far the most attention (Collins, 1992; Kletzer, 2002; Klein et al., 2003; Davidson and Matusz, 2004; Greenaway et al., 2008; Elsby et al. 2013). Figure 3 shows the growth of wage 
inequality within the U.S. manufacturing sector beginning in the early 1970s. This measure of wage inequality is based on the ratio of the average annual wage of non-production workers to the average annual wage of production workers in manufacturing. It has become common in the literature linking trade to wages within the manufacturing sector to use non-production workers as a proxy for skilled workers and to use production workers as a proxy for unskilled workers. From Figure 3, it is clear that wage inequality declined through the 1970s, and then it increased sharply from 1982 through 2000. On average, wages paid to non-production (skilled) workers in manufacturing in 1982 were 1.52 times larger than wages paid to production (unskilled) workers. By 2000 that skilled-unskilled wage ratio in manufacturing had expanded to 1.78, an increase of more than $17 \%$, since which time it has moderately declined.

\section{[FIGURE 3 ABOUT HERE]}

In the early 1990s, a number of authors sought explanations for the steep rise in U.S. wage inequality that marked the preceding decade (Borjas et al., 1992; Lawrence and Slaughter, 1993). Attention quickly moved to demand-side arguments (Katz and Murphy, 1992), with trade and skill-biased technological change seen as most culpable. Empirical analysis of trade impacts was predominantly cross-sectional in nature, with researchers exploiting sectoral variation in import competition, relative commodity prices and wages, informed by the factor content of imports and the claims of Stolper-Samuelson (Freeman and Katz, 1991; Sachs and Schatz, 1994, Baldwin and Cain, 2000) At the time, researchers generally agreed that skill-biased technological change played the largest role in shaping inequality, since the volume of U.S. imports, and especially those from low-wage economies, was regarded as too small to support the observed 
shifts in relative wages (Krugman, 2000). Some push these same arguments today (Edwards and Lawrence 2013); others were not convinced even in the 1990s (Leamer, 1998).

In searching for a more robust link between trade and wages, Feenstra and Hanson (1996, 2001) offered early evidence of the importance of intermediates rather than finished goods in aggregate trade flows and provided a simple model of production in a single industry with two inputs, one unskilled labor intensive and the other skilled labor intensive. Production of the unskilled labor intensive input was set as footloose, located domestically or imported (outsourced), with the share of imports set by the global price of the unskilled labor intensive input relative to its domestic price. In this fashion, Feenstra and Hanson (2001) re-direct factor proportions arguments away from between sector adjustments to within sector adjustments and they report that within U.S. industries the effect of outsourcing on the skilled-unskilled wage premium is of the same form and magnitude as skill-biased technological change.

It is clear from Feenstra and Hanson (2001) that the failure of past studies to reveal a strong relationship between trade and wages may not point to an absent relationship as much as to an outdated conception of global trade (Feenstra, 2008; Krugman, 2008). All trade models implicitly assume that reductions in international trade costs, a combination of tariffs, transportation, and other costs of transacting across distance, have rendered sensible the spatial separation of producers and consumers. But what if recent declines in trade costs, due to fiberoptics networks more than cheap shipping, have now enabled the widespread separation of individual tasks within sectors of the economy? Though difficult to accurately measure, existing data suggest that trade in intermediates and tasks, variously described as task trade, fragmentation, offshoring, outsourcing, or vertical specialization, appears to be quantitatively significant and rapidly growing (Blinder, 2006; Grossman and Rossi-Hansberg, 2006; Baldwin, 
2006; Venables, 2009). Fully 50\% of the rapid growth in merchandise trade between 1962 and 1999 can be attributed to national specialization in subsets of manufacturing production (Yi, 2003). Moreover, the import share of total inputs into U.S. manufacturing more than doubled between 1972 and 2000 (Grossman and Rossi-Hansberg, 2006). Imports of 'Other Private Services,' a category that includes business and professional services, have grown five-fold since 1992 (Bureau of Economic Affairs, 2009). This new spatial separation between subsets of manufacturing and service activities suggests that the locus of comparative/competitive advantage is shifting from industries and finished goods to more fine-grained tasks. If this is indeed the case, estimates of the impacts of trade on labor markets must look to changes within industries, rather than seeking trade effects in the shift of resources between industrial sectors.

Evidence of shifts in the structure of advanced economies from an emphasis on routine to non-routine tasks is provided by Autor et al. (2003), Spitz-Oener (2006) and Goos and Manning (2007). Although task-biased technological change is typically imagined as the source of these shifts, the effect of trade, particularly with developing countries, could conceivably push in the same direction. Ebenstein et al. (2009) explore this idea showing that domestic workers performing non-routine tasks in U.S. multinational enterprises (MNEs) find their wages less strongly affected by trade with subsidiaries in developing economies than workers that perform routine tasks. Similarly, Becker et al. (2008) use micro-data for workers and trade in German MNEs to show that the ratio of non-routine to routine workers in these firms increases with related-party trade with developing economies. Kemeny and Rigby (2012) combine trade, industry, and occupation-task data for U.S. industries to explore the growth of non-routine work in the U.S. economy since the early 1970s. They report a significant, positive relationship 
between trade with low-wage economies and non-routine job growth within U.S. manufacturing industries.

Though the connection between international trade and inequality historically has focused on imports, growing evidence of firm heterogeneity and trade, particularly the characteristics of exporters, links the rise of exports and wage inequality both within the firm and at the industry level (Bernard and Jensen 1999; Bernard et al. 2007; Castellani et al. 2010; Klein et al. 2010). While most such work focuses on developed economies, similar findings are offered for developing countries where there has been considerable skill-upgrading within export-oriented firms (Zhu and Trefler 2005; Bustos 2007; Verhoogen 2008). Indeed, there is growing evidence within low-wage countries, more generally, that increased trade is correlated with rising inequality (Goldberg and Pavenik 2007). The import and export literature is linked by Bas and Strauss-Kahn (2010) who show that increased variety in imports may lead to firm-level productivity gains that encourage exports. Bas (2012) further examines the interaction of exports and technology choice within heterogeneous firms that lead to shifts in the relative demand for skilled labor. Wagner (2012) provides a comprehensive recent review of the trade and firm performance literature consistent with the idea of firm heterogeneity.

What about the timing of the shifts noted above and the relative roles of technological change and trade with low-wage countries in driving the growth of wage inequality within the United States? It is important to note that relatively few papers have examined the recent, post1990, contribution of technological change and trade on relative wages within the United States. Krugman (2008) concurs, noting that the empirical research linking trade and wages is largely outdated. In the few notable exceptions, Sitchinava (2008) extends the capital-goods trade estimates of Feenstra and Hanson (1996) reporting mixed evidence of trade and skill-biased 
technological change impacts for cross-sectional (between) industry models estimated over the periods 1989-1996 and 1997-2004. Ebenstein et al. (2009) examine the period 1982-2002 and show that the impact of offshoring on the U.S. labor market depends on the location of offshore activities, with low-wage offshoring reducing employment and wages particularly in the 1990s. They also reveal that import competition drives employment reallocation between industries with largely negative wage effects for the workers involved. For the services sector, Liu and Trefler (2008) report relatively small U.S. labor market effects of services offshoring to China and India between 1996 and 2006. Shifting to low-wage country imports, a prominent feature of post1990s trade, Bernard et al. (2006) identify multiple forms of response by U.S. manufacturers including exit and product upgrading as well as the reallocation of activity between sectors. They go on to call for more research on the impacts of trade with low-wage economies. This paper is very much a response to that call, detailing for the first time for the United States how technological change and low-wage country import competition has impacted wage inequality for two relatively long periods, the first extending from 1972 to1990 and the second from 1990 to 2005 .

The empirical analysis reported below is motivated by recent theoretical work on trade and labor market impacts. This work largely falls into one of two camps (Neary 2010), the first developed within a framework of perfect competition and comparative advantage extended to incorporate the production and trade of intermediates or tasks (Feenstra and Hanson 2001; Grossman and Rossi-Hansberg 2008), the second resting on product differentiation and monopolistic competition (Melitz 2003; Yeaple 2005; Helpman et al. 2010). It is the former that underpins our empirical model. The crux of this theoretical work is to establish how intraindustry trade in some segment of the production chain shifts relative demand and wages toward 
high-skilled workers. This is conventionally achieved by allowing production to fragment across trading nations and by assuming that the production of intermediate inputs is intensive in their use of either skilled labor or unskilled labor (Ethier 2005). Feenstra and Hanson (2001) develop these arguments assuming that unskilled labor and imported intermediates are substitutes and thus a decrease in the unit price of an imported input will cause a decrease in domestic demand and the relative price of unskilled labor. Grossman and Rossi-Hansberg (2008) outline a similar model of trade in tasks, the separable pieces of work performed in the production process. For Grossman and Rossi-Hansberg (2008) the decision to offshore tasks is dependent upon the costs of monitoring and controlling workers at a distance in relation to the potential benefits of lower wages in foreign countries. Those costs are assumed lower for routine tasks typically performed by low-wage workers rather than for non-routine tasks typically performed by high-wage workers (Autor et al. 2003). The greater tendency to offshore routine tasks is hypothesized to increase wage inequality. Parro (2013) extends this literature offering a general equilibrium model of "skill-biased trade" resting on the complementarity between capital and skilled labor that provides additional theoretical support for trade-inequality links in both developed and developing economies. Kurokawa (2011) also adds to this literature, developing a model of the complementarity of variety in what is available to trade with skilled labor, with tariff reductions increasing variety in trade and driving relative demand for skilled labor.

Our approach is also related to recent empirical papers motivated by these same theoretical developments (see Ekholm and Midelfart 2005; Ebenstein et al. 2009; Kemeny and Rigby 2012) and that in various ways seek to explore how the geographical fragmentation of production stages and tasks has affected the demand for workers of various types. Like all these papers, we regress the relative wages of skilled to unskilled workers within an industry on a 
sector-specific measure of low-wage country import competition and a measure of technological change, with other industry characteristics as controls. We do not explicitly trace the flows of low-wage country intermediates throughout the U.S. economy, following Freeman and Hanson (2001), in part because we share some of the concerns of Houseman (2011) and Sitchinava (2008) on bias in this measure of offshoring, explored further by Feenstra and Jensen (2012).

We bypass this concern showing that aggregate measures of import competition are sufficient to sustain the claim that imports from low-wage countries are related to increasing wage inequality in U.S. manufacturing.

Thus, we add to the literature examining import competition and rising wage inequality within the U.S. economy through our explicit focus on imports from low-wage economies and through our investigation of a temporal change in the nature of the relationship between lowwage imports and relative wages in U.S. manufacturing. We show that import competition from low-wage economies emerged as a significant force shaping wage inequality in the United States only from the late-1980s/early-1990s, precisely when U.S. imports from low-wage economies, particularly China, accelerated sharply.

\section{Data and Methods}

In order to explore the impact of low-wage imports on wage inequality within sectors of the U.S. economy we combine annual data on U.S. imports from low-wage countries together with industrial accounts available at the 4-digit (SIC) level. Our data span 459 industrial sectors and 34 years. The trade data originate from the work of Robert Feenstra, funded by the National Science Foundation and National Bureau of Economic Research (NBER). The industry series is drawn from the NBER-Center for Economic Studies (CES) Manufacturing Productivity 
Database currently assembled by Bartelsman, Becker and Gray (Bartelsman and Gray, 1996). Though this dataset offers a wealth of industry-specific information, including capital stocks, wages and total factor productivity, it does not provide measures of worker skills or levels of education. However, it does distinguish wages for production and non-production workers. As is customary in the literature, we classify non-production workers as skilled and production workers as unskilled. This permits calculation of changes in the relative wages of skilled and unskilled workers, our proxy for wage inequality.

Empirical analysis of the link between trade and wage inequality is based upon a relatively standard model specification (Feenstra and Hanson, 1996; Ebenstein et al., 2009; Kemeny and Rigby, 2012)

$$
y=f(S, K, S B T C, T C L W C)
$$

where $y$ represents the ratio of the average wages of non-production to production workers, $S$ represents shipments, $K$ measures capital intensity, SBTC represents skill-biased technological change and TCLWC represents trade or import competition from low-wage countries. In the analysis below we also examine the impacts of the independent variables on the wages of production workers and non-production workers separately.

We estimate the relationship in equation (1) using data for all 4-digit (SIC) manufacturing industries for each year from 1972 to 2005. We relax the assumption that the regression function is constant across industrial sectors by allowing each industry to have its own constant $\left(a_{i}\right)$ that captures industry specific characteristics that are assumed fixed over time. $\epsilon$ represents an error term that we assume possesses the usual properties. This leads to the following econometric specification 


$$
y_{i t}=a_{i}+\beta_{1} S_{i t}+\beta_{2} K_{i t}+\beta_{3} S B T C_{i t}+\beta_{4} T C L W C_{i t}+\epsilon_{i t}
$$

where $i$ indexes industries and $t$ represents years.

To focus attention on changes in these variables within industries, we adopt a panel specification, taking advantage of the temporal component of our data. Theory does not discount the probability that unobserved heterogeneity is correlated with the independent variables in our model, thus mandating use of a fixed effects panel of the following form

$$
\begin{gathered}
y_{i t}-\bar{y}_{i}=a_{i}-a_{i}+\beta_{1}\left(S_{i t}-\bar{S}_{i}\right)+\beta_{2}\left(K_{i t}-\bar{K}_{i}\right)+\beta_{3}\left(S B T C_{i t}-\overline{S B T C}_{i}\right)+ \\
\beta_{4}\left(T C L W C_{i t}-\overline{T C L W C}_{i}\right)+z \boldsymbol{\beta}+\varepsilon_{i t}-\bar{\varepsilon}_{i}
\end{gathered}
$$

where the vector $\mathbf{z}$ represents annual dummy variables, added after time-demeaning the other components of equation (3). In this case, a base-year is chosen for analysis and the coefficient vector $(\boldsymbol{\beta})$ on the time dummies indicates the size of individual year specific shocks to the economy as a whole relative to the omitted base-year dummy.

Letting $\tilde{X}_{i t}=X_{i t}-\bar{X}_{i}$, we estimate the following equation

$$
\tilde{y}_{i t}=\beta_{1} \tilde{S}_{i t}+\beta_{2} \widetilde{K}_{i t}+\beta_{3} \widetilde{S B T C}_{i t}+\beta_{4} T \widetilde{C L W} C_{i t}+\mathbf{z} \boldsymbol{\beta}+\tilde{\varepsilon}_{i t}
$$

In the analysis that follows, all continuous variables are logged and dollar denominated values are deflated using the sector-specific deflators available in the NBER-CES industry data.

For each industry, trade competition from low-wage economies is defined as

$$
T C L W C_{i t}=\frac{\text { IMPORTS FROM LWCS }}{\text { it }}
$$

where the import and export values in the denominator are measured across all countries that trade with the U.S.. This measure represents the portion of good $i$ in year $t$ available for 
domestic consumption in the United States that is exported by a low-wage country. The set of countries comprising the LWC group includes "Low Income" or "Lower Middle Income" economies according to the World Bank's World Development Indicators. We use World Bank definitions for 1988, the mid-point of our study period. Figure 4 reports values of U.S. trade competition from LWCs and from all trade partners. These trade competition measures are shown as indices with values set at 1 in 1972. The index of overall U.S. import competition increased by a factor of 5 since 1972, while LWC import competition increased by a factor of 24 .

\section{[FIGURE 4 ABOUT HERE]}

Lacking direct measures of skill-biased technological change (SBTC), we use total factor productivity (TFP) as a proxy, available for each industry in all years examined. We recognize that TFP is a general indicator of technological change rather than a measure of SBTC, and so as a robustness check we also use the computer share of total capital investment available from the Census of Manufactures to represent SBTC. Both these measures have been repeatedly used in past research as proxies for skill-biased technological change. While the computer investment data cover all 4-digit SIC manufacturing industries, they are available for only a few years of our study period. In all regressions below, we incorporate (Huber-White) robust standard errors to control for potential heteroscedasticity. A Hausman test further suggests use of the fixed effects model over the random effects alternative.

\section{Results}

The starting point of our analysis is a fixed effects panel model estimated using ordinary least squares. Our attention focuses on the partial regression coefficients linking the dependent 
variable to import competition from low-wage countries and to skill biased technological change, the latter proxied by measures of total factor productivity. In general, we anticipate that LWC import competition will lower the relative wage of production (unskilled) workers, and that skillbiased technological change should do the same. For all models in Table 1, results indicate that most of the variance in the dependent variables is explained by differences between industries. An $F$-test indicates that these industry differences are significant and thus pooled OLS is an inappropriate estimation strategy.

\subsection{Baseline Estimates}

Model 1 in Table 1 represents a base model for the period 1972-1990, capturing results that are broadly consistent with research from the early 1990s. As with much of the early literature, this model measures import competition from all countries that export to the United States, not just developing economies. The dependent variable is the logarithm of the ratio of wages between non-production (skilled) and production (unskilled) workers. Column 2 in Table 1 shows that only TFP, our indicator of skill-biased technological change, is significantly related to the change in relative wages within industries. Consistent with our theoretical priors, TFP is positively associated with inequality over this period. Overall import competition has no significant relationship with wage inequality.

\section{[TABLE 1 ABOUT HERE]}

In the next three models in Table 1, we turn our attention to imports from low-wage countries and to the full period under study, 1972-2005. Three different dependent variables are 
examined. In Model 2, the dependent variable is the average wage of production (unskilled) workers. Model 3 predicts how trade and technology are related to the average wage of nonproduction (skilled) workers. Model 4 measures how these key variables affect inequality, as measured by the ratio of the average wages of non-production to production workers. Over the study period as a whole, trade competition from low-wage countries exerts a significant and negative impact on the average wages of unskilled workers, while it has no significant influence on the average wage of skilled workers. Thus, the net effect of import competition from lowwage countries is an increase in wage inequality between skilled and unskilled workers. Skillbiased technological change has no significant impact on wage inequality for the study-period overall, though consistent with theoretical expectations, the coefficient for TFP is larger for more-skilled rather than less-skilled workers.

\subsection{Endogeneity}

These relationships, while suggestive, ignore potential bias as a result of endogeneity. The results in Table 1 assume that import competition and technological change each exert an exogenous influence on firms and the wages that they provide. However, trade, technology and wages might be related in a quite different manner. Specifically, some firms might decide to offshore a subset of their production activities, changing domestic technology while also giving rise to increased trade. The potential for reverse causation in our model suggests use of instrumental variables techniques to examine endogeneity bias. Lacking an ideal set of exogenous variables, we use one-, two- and three-year lags of our right hand side variables to serve as instruments. The generalized method of moments (GMM) estimator is used because it produces consistent and efficient estimates when errors are not independent and identically distributed (iid). When the 
estimating equation is overidentified, the GMM estimator also provides a useful set of diagnostics for identification tests as well as the exogeneity of instruments. Finally, using Newey-West estimators in conjunction with GMM techniques, we produce estimates that are robust to heteroscedasticity and serial correlation up to a specified order (3 years in the analysis below).

Table 2 reports results from using instrumental variables estimates within a GMM framework. As expected, the standard errors on most variables have been reduced. We estimate two models in Table 2. In Model 1, we treat all independent variables as endogenous. Using one, two and three period lags of all predictors as instruments, we find that rising import competition from low-wage countries has a positive and significant impact on wage inequality. The sign on the TFP variable (our measure of skill-biased technological change) is negative, running counter to theoretical expectation, though this variable is not significant. The diagnostics from the IV fixed effects panel models are sound: first-stage regressions (which we omit for brevity) pass underidentification and weak identification tests, and the Hansen J-statistic reveals that our instrument set can be considered exogenous.

\section{[TABLE 2 ABOUT HERE]}

Following endogeneity tests on all regressors, in our second model we treat shipments and capital intensity as exogenous. Our measures of skill-biased technological change and import competition could not be considered exogenous from these tests. Results from this second IV model are similar to those from Model 1: rising LWC import competition increases wage inequality between skilled and unskilled manufacturing workers in the United States, while skillbiased technological change has no significant influence. 


\subsection{Timing Issues: Distinct Periods for Trade Impacts?}

Given the general effects we report in Tables 1 and 2, we now investigate whether the impacts of trade and technology on relative wages vary across different time periods. There is some rationale for doing so. First, we know that skill-biased technological change ought to have been important during the 1980s and into the early 1990s, tracking the introduction of computing technology into the workplace. We also know that imports from low-wage economies, particularly China, began to accelerate rapidly after 1990. These temporal patterns might help explain why the majority of early studies (published before 1995, and mostly studying the 1980s) find that technology exerts a far larger influence on rising wage inequality than trade. To test this argument, we divide our period of investigation into two sub-periods, pre-1990 and post-1990, and re-estimate Equation (4) for each sub-period, using instrumental variables techniques as above. $^{3}$

We present the results of these estimates in Table 3. Models 1 and 2 in Table 3 present results from estimating Equation (4) for the initial period, 1972-1990. Our findings are similar to those obtained from the majority of studies that explored the effects of skill-biased technological change and trade on relative wages through the 1980s. In Model 1, all independent variables are treated as endogenous. The results show that none of the predictors exert a significant effect on wage inequality.

\footnotetext{
${ }^{3}$ Moving the cut date a few years either side of 1990 has little influence on the model results that are displayed in Table 3. We also explored shifting the threshold to 1994, on the basis that at this date the North American Free Trade Agreement (NAFTA) was ratified. However, this year did not signal a large uptick in overall low-wage country imports; rather, the shift appears to occur right around 1990. This 1990 cut date is also used by Autor, Dorn, and Hanson (2011) as the start of substantial shifts in import levels from low-wage economies, in their case, specifically China.
} 


\section{[TABLE 3 ABOUT HERE]}

On further inspection, however, in this early period endogeneity tests support treating skillbiased technological change and import competition as exogenous. This is done in model 2, where the results conform to existing literature: skill-biased technological change increased wage inequality through the 1980s, while the influence of trade from low-wage economies was insignificant.

In Models 3 and 4 that track the post-1990 period, the results change considerably. Since the early-1990s, rising wage inequality in the United States appears to be driven largely by increased import competition from low-wage economies. The impact of skill-biased technological change on wage inequality is insignificant after 1990. Endogeneity tests for the post-1990 data support treatment of shipments and capital intensity variables as exogenous. Thus, in model 4, only technological change and import competition are estimated with instruments. As with the previous model, results indicate that import competition from LWCs is the primary driver of wage inequality in the U.S. since 1990. Skill-biased technological change has no significant influence on wage inequality.

To bolster confidence in these results, we re-estimate our model using an alternative measure of skill-biased technological change. Though total factor productivity is widely used as a proxy for skill-biased technological change, it is likely an imperfect one. While the literature on skill-biased technological change is chiefly concerned with the dramatic and widespread adoption of computer technology in the workplace, rates of growth of total factor productivity have been relatively modest since the 1970s. To ensure that our findings are not driven by the imperfections of our proxy, we produce a final set of results where skill-biased technological change is measured as the computer share of total capital investment, using the Census of 
Manufactures' data on sector-specific spending on 'computers and peripheral data processing equipment.' Though appealing on a conceptual level, this variable is available for relatively few years. We employ it here first using just two years, 1982 and 1992, that cover the period during which computer investment increased most rapidly across U.S. manufacturing. ${ }^{4}$ A second model is run over the three years 1992, 2002 and 2005, representing the second part of our study period.

\section{[ TABLE 4 ABOUT HERE]}

Table 4 presents the results from models in which the computer share of total capital investment is our measure of skill-biased technological change. Diagnostic tests for the models in Table 4, with a longer time-step, show that all independent variables are exogenous and so we run a simple fixed effect panel model, including year fixed effects. Model 1 indicates that increases in the computer share of investment have a significant and positive impact on wage inequality over the period 1982 to 1992, while the influence of trade competition from low-wage economies is insignificant at this time. Results from Model 2, for the period after 1992, indicate that the computer share of investment has no significant influence on wage inequality, while trade competition from the developing world has a significant positive influence on wage inequality. The results in Table 4 are entirely consistent with those from the work presented above and thus we have confidence in use of total factor productivity as a proxy for skill biased technological change.

\footnotetext{
${ }^{4}$ The Census of Manufactures is collected every five years in years ending in ' 2 ' and ' 7 .' This explains why the results in Table 4 break the pre-/post-1990s period at 1992 rather than 1990.
} 


\section{Conclusion}

Global trade patterns have shifted dramatically since the early-1990s, with low-wage economies, most notably China, exporting ever larger volumes of goods and services to advanced, industrialized economies. These trends presage the emergence of a third trade regime following the East-West flows between developed economies that characterized monopolistic competition in the 1970s. Indeed, the growth of import competition from LWCs to the United States increased by a factor of 30 between 1970 and 2005, compared with a growth factor of just 5 for import competition from all U.S. trade partners combined.

Shifts in the structure of global trade flows and their influence on economies around the world have generated considerable alarm. An earlier round of investigation on trade impacts in developed economies concluded that import competition had little impact on the rapid growth of wage inequality in the 1980s. The primary driver of the steep rise in the relative wages of skilled workers over that decade appears to have been skill-biased technological change. The research here confirms this finding, but goes on to show that continued growth in U.S. wage inequality since the early-1990s is largely the result of rising import competition. Specifically, we show that since 1990, skill-biased technological change has played no role in the continued expansion of the skilled worker-unskilled worker wage gap in U.S. manufacturing. Over the last fifteen years, the growth of U.S. wage inequality has been driven largely by increased trade competition from developing countries.

There is little reason to expect that the growth of trade competition from developing economies will decline in the medium term. Though the recent global economic downturn temporarily depressed trading activity, there is widespread agreement that imports and offshoring activities are recovering and that they will continue to intensify in the future. The fact that 
routinized and less skill-intensive economic activities are increasingly being moved to lower cost locations suggests that demand for "unskilled" production workers may be further depressed. How should we respond? The potential gains from trade are clear: increased productivity and lower costs for many commodities. On the one hand we all benefit from trade. On the other hand, the costs of trade are distributed unevenly. In general, those costs are borne disproportionally by countries that are unable to shift the terms of trade in their favor and by different groups of workers within developed and developing countries alike. Within advanced, industrialized economies such as the United States, less-skilled workers and those engaged in routine tasks face the greatest threat from globalization. Trade barriers are too blunt a policy instrument to mitigate the negative consequences of trade. Increased investment in education and worker retraining initiatives are obvious possibilities, but many of our international competitors are climbing the skill ladder just as surely as we are. Education alone may not prove a viable long-run hedge against the negative consequences of global competition. 


\section{REFERENCES}

Autor, D., D. Dorn, and G. Hanson 2011 The China syndrome: local labor market effects of import competition in the United States. Mimeo.

Autor, D., Levy, F. and R. Murnane 2003. The skill content of recent technological change: an empirical exploration. Quarterly Journal of Economics 118: 1279-1333.

Baldwin, R. 2006. Globalisation: the great unbundling(s). Finnish Prime Minister's Office for EU Presidency.

Baldwin, R. and G. Cain 2000. Shifts in relative US wages: the role of trade, technology and factor endowments. Review of Economics and Statistics 82: 580-595.

Bartelsman, E. and W. Gray 1996. The NBER manufacturing productivity database. NBER Technical Working Paper No. 205.

Bas, M. 2012. Technology adoption, export status, and skill upgrading: theory and evidence. Review of International Economics, 20:315-331

Becker, S., Ekholm, K., and Muendler, M. 2008. Offshoring and the onshore composition of occupations, tasks and skills. Technical report, mimeo.

Bernard, A. and J. Jensen 1999. Exceptional exporter performance: cause, effect, or both? Journal of international Economics 47: 1-25.

Bernard, A., J. Jensen and P. Schott 2006. Survival of the best fit: Exposure to low-wage countries and the (uneven) growth of US manufacturing plants. Journal of International Economics 68:219-237.

Bernard, A., Jensen, J., Redding. S. and P. Schott 2007. Firms in international trade. NBER Working Paper 13054.

Bivens, J. 2007. Globalization and American wages: today and tomorrow. Economic Policy Institute Briefing Paper 196. Washington, DC

Blinder, A. (2006). Offshoring: the next industrial revolution. Foreign Affairs 85:113-128.

Bluestone, B. and B. Harrison 1982. The Deindustrialization of America: New York: Basic Books.

Borjas, G., Freeman, R. and L. Katz 1992. On the labor market effects of immigration and trade. In Borjas, G. and R. Freeman (eds.) Immigration and the Workforce. Chicago: Chicago University Press, 213-244. 
Bureau of Economic Affairs 2009. Trade in service: 1992-2007. Technical report, Bureau of Economic Affairs. http://www.bea.gov/international/intlserv.htm Retrieved February 29, 2009.

Bustos, P. 2007. The impact of trade on technology and skill upgrading. Evidence from Argentina. University Pompeu Fabra, Dept. de Economica y Empresa \# 1189.

Castellani, D., Serti, F. and C. Tomasi 2010. Firms in international trade: Importers' and exporters' heterogeneity in Italian manufacturing industry. The World Economy 33: 424-457.

Coe, N. M., Hess, M., Yeung, H. W., Dicken, P. and Henderson, J. 2004. 'Globalizing' regional development: a global production networks perspective. Transactions of the Institute of British Geographers 29: 468-484

Collins, S. 1992. Economic integration and the American worker: an overview. In Collins, S. (ed.) Imports, Exports, and the American Worker. Washington DC: Brookings Institution Press.

Davidson, C. and S. Matusz 2004. International Trade and Labor Markets. Kalamazoo: Upjohn Institute for Employment Research.

Ebenstein, A., Harrison, A., McMillan, M., Phillips, S., and Hall, G. 2009. Estimating the Impact of Trade and Offshoring on American Workers Using the Current Population Surveys. NBER Working Paper.

Edwards, L. and R. Lawrence 2013. Rising tide: Is growth in emerging economies good for the United States? Peterson Institute for International Economics.

Ekholm, K. and K. Midlefart 2005. Relative wages and trade-induced changes in technology. European Economic Review 49: 1637-1663.

Elsby, M., Honijn, B. and S. Aysegul 2013. The decline of the U.S. labor share. Brookings Panel on Economic Activity, September 19-20, 2013.

Ethier, W. 2005. Globalization, Globalisation: Trade, technology and wages. International Review of Economics and Finance 14: 237-258.

Feenstra, R. and G. Hanson 1996. Globalization, outsourcing, and wage inequality. American Economic Review 86: 240-245.

Feenstra, R. and G. Hanson 2001. Global production sharing and rising inequality: a survey of trade and wages. NBER Working Paper No. 8372.

Feenstra, R. and B. Jensen 2012. Evaluating estimates of materials offshoring from U.S. manufacturing. Economics Letters 117: 170-173. 
Freeman, R. and Katz, L., 1991. Industrial wage and employment determination in an open economy. In: Abowd, John M., Freeman, Richard B. (Eds.), Immigration, Trade and Labor Market. University of Chicago Press: Chicago.

Gereffi, G. 1994. Commodity Chains and Global Capitalism. New York: Preager.

Goldberg, P. and N. Pavcnik 2007. Distributional effects of globalization in developing countries. Journal of Economic Literature XLV: 39-82.

Goos, M. and Manning, A. 2007. Lousy and lovely jobs: The rising polarization of work in Britain. The Review of Economics and Statistics, 89: 118-133.

Greenaway, D., Upward, R. and P. Wright (eds.) 2008. Globalisation and Labour Market Adjustment. Basingstoke: Palgrave Macmillan.

Grossman, G. and E. Rossi-Hansberg 2006. The rise of offshoring: Its not wine for cloth anymore. Federal Reserve Bank of Kansas City symposium, The New Economic Geography: Effects and Policy Implications, Jackson Hole, Wyoming, August, page 2426.

Grossman, G. and E. Rossi-Hansburg 2008. Trading Tasks: A Simple Theory of Offshoring. American Economic Review 98: 1978-1997.

Haskell, J. and M. Slaughter 1998. Does the sector bias of skill-biased technical change explain changing wage-inequality? NBER Working Paper No. 6565.

Helpman, E., O. Itshoki, , and S. Redding 2010. Inequality and unemployment in a global economy. Econometrica 78: 1239-1283.

Houseman, S., Kurz, C., Lengermann, P. and B. Mandel 2011. Offshoring bias in U.S. manufacturing. Journal of Economic Perspectives 25: 111-132.

Katz, L. and K. Murphy 1992. Change in relative wages, 1963-1987: supply and demand factors. Quarterly Journal of Economics 107: 35-78.

Kemeny, T. and D. Rigby 2012. Trading away what kind of jobs? Globalization, trade and tasks in the U.S. economy. Review of World Economics 148: 1-16.

Klein, M., Schuh, S. and R. Triest 2003. Job Creation, Job Destruction, and International Competition. Kalamazoo: Upjohn Institute for Employment Research.

Klein, M., Moser, C. and D. Urban 2010. The contribution of trade to wage inequality: The role of skill, gender, and nationality. NBER Working Paper \# 15985.

Kletzer, L. 2002. Imports, Exports, and Jobs. Kalamazoo: Upjohn Institute for Employment Research. 
Koopman, R. and Wang, Z. and Wei, S.J. 2008. How much of Chinese exports is really made in China? Assessing domestic value-added when processing trade is pervasive. NBER Working Paper No. 14109 .

Krugman, P. 2000. Technology, trade and factor prices. Journal of International Economics 50: $51-71$.

Krugman, P. 2008. Trade and wages reconsidered. Unpublished manuscript, Princeton University.

Kurokawa, Y. 2011. Variety-skill complementarity: a simple resolution of the trade-wage inequality anomaly. Economic Theory 46:297-325.

Lawrence, R. and M. Slaughter 1993. Trade and US wages: Great sucking sound or small hiccup? Brookings Papers on Economic Activity, Microeconomics. Washington DC: Brookings Institution, 161-211.

Leamer, E. 1998. In search of Stolper-Samuelson linkages between international trade and lower wages. In: S. Collins (Ed.), Imports, Exports and the American Worker, Brookings, Washington (1998), pp. 141-202.

Levy, F. and R. Murnane 1992. U.S. earnings levels and earnings inequality: a review of recent trends and proposed explanations. Journal of Economic Literature 30: 1333-1381.

Liu, R. and D. Trefler 2008. Much ado about nothing: American jobs and the rise of services outsourcing to China and India. NBER Working Paper \# 14061.

Melitz, M. 2003. The impact of trade on intra-industry reallocations and aggregate industry productivity. Econometrica 71: 1697-1725.

Neary, J.Peter 2010. Two and a half theories of trade. The World Economy 33: 1-19.

Parro, F. 2013. Capital-skill complementarity and the skill premium in a quantitative model of trade. American Economic Journal: Macroeconomics 5: 117-132.

Richardson, D. 1995. Income inequality and trade: how to think, what to conclude. Journal of Economic Perspectives 9: 33-55.

Rodrik, D. 2006. What's so special about Chinese exports? China and the World Economy 14: 119.

Sachs, J. and H. Schatz 1994. Trade and jobs in US manufacturing. Brookings Papers on Economic Activity. Washington, DC: Brookings Institution, 1-84.

Schott, P. 2008. The relative sophistication of Chinese exports. Economic Policy 23: 5-49. 
Sitchiniva, N. 2008.Trade, technology and wage inequality: Evidence from U.S. manufacturing 1989-2004. University of Oregon, Dept. of Economics, PhD Dissertation.

Spitz-Oener, A. (2006). Technical change, job tasks, and rising educational demands: Looking outside the wage structure. Journal of Labor Economics 24: 235-270.

Thurow, L. 1984. The disappearance of the middle-class. The New York Times February 5.

Venables, A. 2009. Rethinking economic growth in a globalizing world: an economic geography lens. African Development Review 21: 331-351.

Verhoogen, E. 2008. Trade, quality upgrading, and wage inequality in the Mexican manufacturing sector. The Quarterly Journal of Economics May: 489-530.

Wagner, J. 2012. International trade and firm performance: A survey of empirical studies since 2006. Review of World Economics 148: 235-267.

Yeaple, S. 2005. A simple model of firm heterogeneity, international trade, and wages. Journal of International Economics 65: 1-20.

Yi, K. 2003. Can vertical specialization explain the growth of world trade? Journal of Political Economy 111: 52-102.

Zhu, S.C. and D. Trefler. 2005. Trade and inequality in developing countries: a general equilibrium analysis. Journal of International Economics 65(1): 21-48. 


\section{TABLES AND FIGURES}

Figure 1: Manufactured Imports to the United States

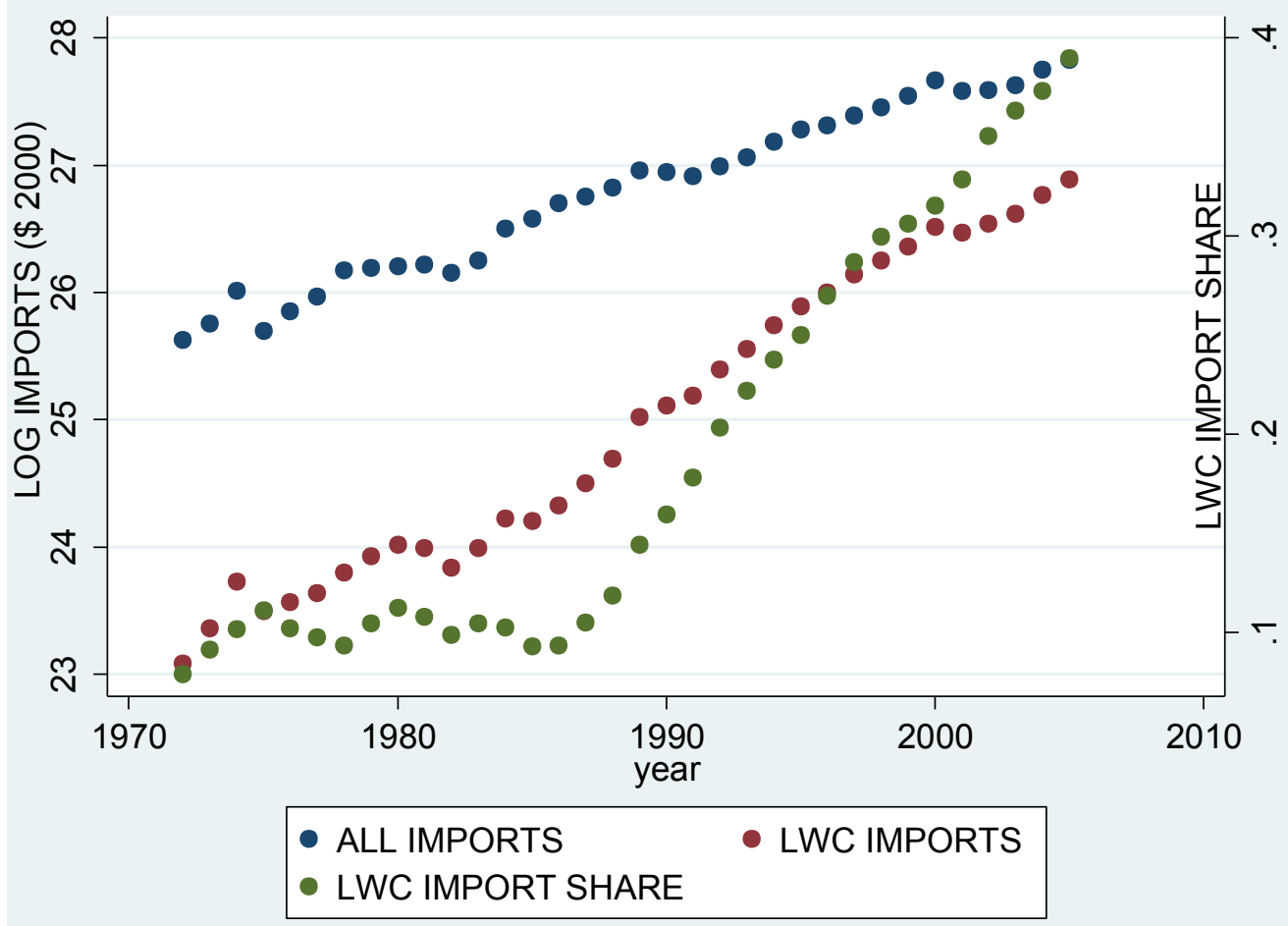


Figure 2a: U.S. Imports from Low-Wage Countries: 1972-2006

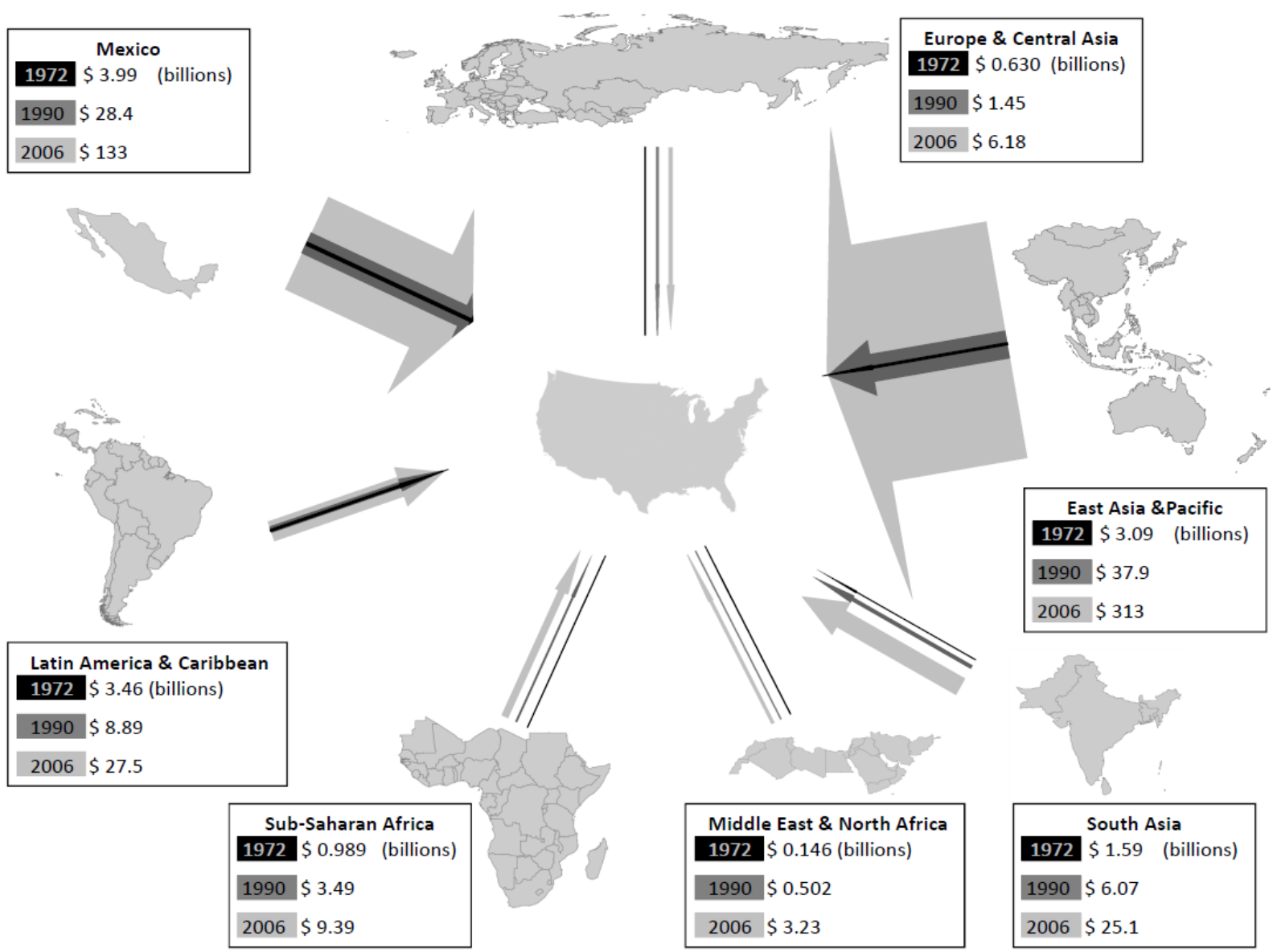


Figure 2b: U.S. Imports from Industrialized Countries: 1972-2006

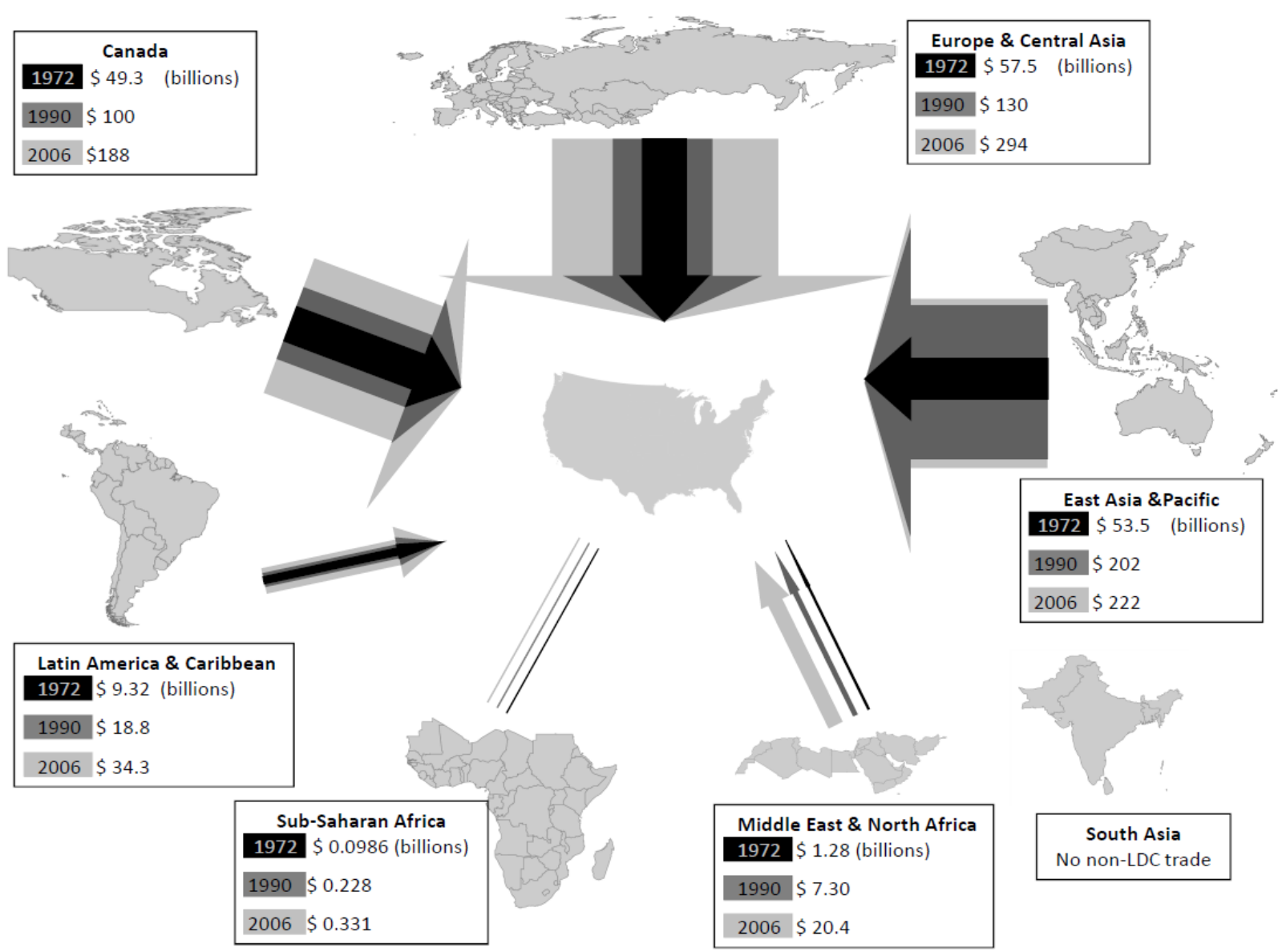

Notes: Industrialized countries are defined as medium- and high-wage economies according to the World Bank in 1988 . 
Figure 3: Wage Inequality in U.S. Manufacturing

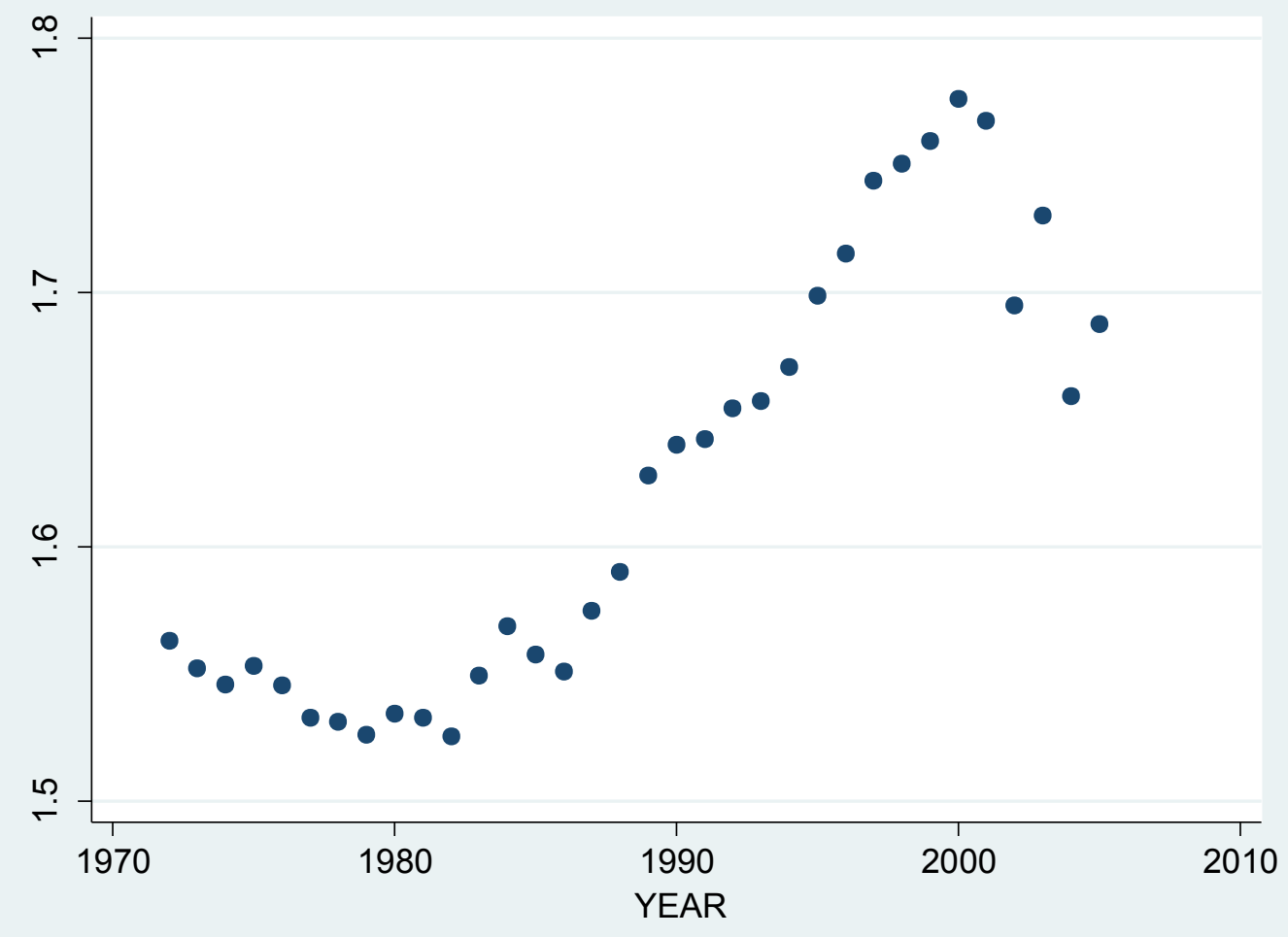


Figure 4: Index of U.S. Import Competition from Low-Wage Countries and Overall

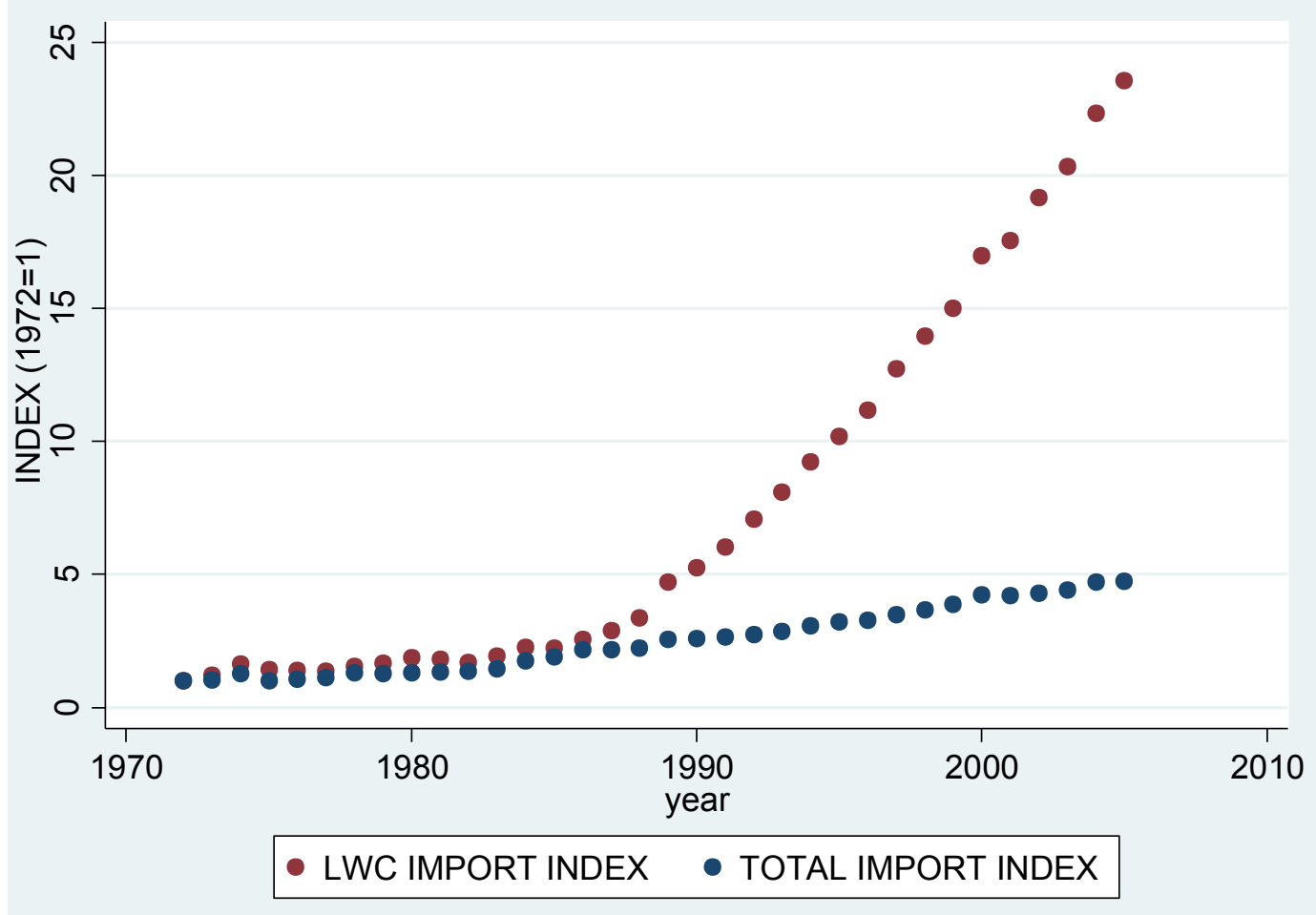


Table 1: The Impact of Import Competition and Technology on Wage Inequality; Fixed Effect Panel (OLS)

\section{Independent Variables}

\section{Dependent Variables}

\begin{tabular}{|c|c|c|c|c|}
\hline & $\begin{array}{c}\text { Model 1 } \\
\text { 1972-1990 } \\
\text { Wage Ratio }\end{array}$ & $\begin{array}{c}\text { Model 2 } \\
\text { 1972-2005 } \\
\text { Avg Wage } \\
\text { (Production) } \\
\end{array}$ & $\begin{array}{c}\text { Model 3 } \\
1972-2005 \\
\text { Avg Wage } \\
\text { (Non-Production) } \\
\end{array}$ & $\begin{array}{c}\text { Model } 4 \\
\text { 1972-2005 } \\
\text { Wage Ratio }\end{array}$ \\
\hline Shipments & $\begin{array}{l}-0.000550 \\
(0.02049)\end{array}$ & $\begin{array}{c}0.06339 * * * \\
(0.01144)\end{array}$ & $\begin{array}{c}0.06185^{* * *} \\
(0.01153)\end{array}$ & $\begin{array}{l}-0.00154 \\
(0.01254)\end{array}$ \\
\hline Capital Intensity & $\begin{array}{c}0.03964 \\
(0.02474)\end{array}$ & $\begin{array}{c}0.04659^{* * *} \\
(0.01399)\end{array}$ & $\begin{array}{c}0.06360 * * * \\
(0.01501)\end{array}$ & $\begin{array}{c}0.01692 \\
(0.01604)\end{array}$ \\
\hline TFP & $\begin{array}{l}0.07217^{*} \\
(0.04078)\end{array}$ & $\begin{array}{c}0.02273 \\
(0.02010)\end{array}$ & $\begin{array}{l}0.030156 \\
(0.02272)\end{array}$ & $\begin{array}{c}0.00720 \\
(0.02389)\end{array}$ \\
\hline $\begin{array}{l}\text { Import Competition } \\
\text { (LWCs) }\end{array}$ & & $\begin{array}{c}-0.00402 * * \\
(0.00174)\end{array}$ & $\begin{array}{c}0.00139 \\
(0.00171)\end{array}$ & $\begin{array}{c}0.00532 * * * \\
(0.00202)\end{array}$ \\
\hline $\begin{array}{l}\text { Import Competition } \\
\text { (All) }\end{array}$ & $\begin{array}{l}-0.00152 \\
(0.00443)\end{array}$ & & & \\
\hline Observations & 5862 & 11487 & 11486 & 11486 \\
\hline R-squared (within) & 0.0333 & 0.9725 & 0.9506 & 0.0783 \\
\hline
\end{tabular}

Notes: All variables are logged. Year fixed effects included but not shown. All models were estimated with a constant. Robust standard errors are shown in parentheses. * indicates significant at the 0.1 level, ** indicates significant at the 0.05 level, $* * *$ indicates significant at the 0.01 level. 
Table 2: The Impact of Import Competition and Technology on Wage Inequality, 19722005; Instrumental Variables Estimation (2-stage GMM)

\begin{tabular}{|c|c|c|}
\hline \multirow[t]{2}{*}{$\begin{array}{l}\text { Independent } \\
\text { Variables }\end{array}$} & \multicolumn{2}{|c|}{$\begin{array}{c}\text { Dependent Variable: } \\
\text { Wage Ratio }\end{array}$} \\
\hline & $\begin{array}{l}\text { Model 1 } \\
\text { All independent vars. } \\
\text { treated as endogenous }\end{array}$ & $\begin{array}{c}\text { Model } 2 \\
\text { TFP and Imports treated as } \\
\text { endogenous }\end{array}$ \\
\hline Shipments & $\begin{array}{l}-0.00204 \\
(0.01037)\end{array}$ & $\begin{array}{l}-0.00089 \\
(0.01023)\end{array}$ \\
\hline Capital Intensity & $\begin{array}{c}0.01284 \\
(0.013850)\end{array}$ & $\begin{array}{c}0.00918 \\
(0.01351)\end{array}$ \\
\hline TFP & $\begin{array}{l}-0.01374 \\
(0.02161)\end{array}$ & $\begin{array}{l}-0.01374 \\
(0.02156)\end{array}$ \\
\hline Import Competition (LWCs) & $\begin{array}{c}0.00747 * * * \\
(0.00223)\end{array}$ & $\begin{array}{c}0.00753 * * * \\
(0.00223)\end{array}$ \\
\hline $\begin{array}{l}\text { Observations } \\
\text { R-squared } \\
\text { Root MSE }\end{array}$ & $\begin{array}{l}10055 \\
0.0870 \\
0.1138\end{array}$ & $\begin{array}{l}10055 \\
0.0871 \\
0.1138\end{array}$ \\
\hline $\begin{array}{l}\text { Underidentification Test } \\
\text { (Kleibergen-Paap rk LM statistic) } \\
\text { Chi-sq } p \text {-value }\end{array}$ & $\begin{array}{l}410.217 \\
(0.0000)\end{array}$ & $\begin{array}{l}413.772 \\
(0.0000)\end{array}$ \\
\hline $\begin{array}{l}\text { Weak Identification Test } \\
\text { (Cragg-Donald Wald F-statistic) } \\
\text { (Kleibergen-Paap rk Wald F-statistic) }\end{array}$ & $\begin{array}{c}1145.49300 \\
264.672\end{array}$ & $\begin{array}{c}1148.227 \\
265.557\end{array}$ \\
\hline $\begin{array}{l}\text { Overidentification Test: } \\
\text { (Hansen J-statistic) } \\
\text { Chi-sq } p \text {-value }\end{array}$ & $\begin{array}{c}11.879 \\
(0.1567) \\
\end{array}$ & $\begin{array}{r}13.914 \\
(0.1770) \\
\end{array}$ \\
\hline $\begin{array}{l}\text { Notes: All variables are logged. Year fixed eft } \\
\text { indicates significant at the } 0.05 \text { level, } * * * \text { indi } \\
\text { Bartlett kernel ensure estimates are robust to a } \\
\text { model } 1 \text {, where all independent variables wer } \\
\text { were utilized as instruments. In model } 2 \text {, three }\end{array}$ & $\begin{array}{l}\text { but not shown. } * \text { indi } \\
\text { l correlation up to orde } \\
\text { ndogenous, three perio } \\
\text { of TFP and Import Con }\end{array}$ & $\begin{array}{l}\text { S significant at the } 0.1 \text { level, } \\
\text { ey-West standard errors with } \\
\text { and to heteroscedasticity. In } \\
\text { gs of all independent variable } \\
\text { ition were used as instrument }\end{array}$ \\
\hline
\end{tabular}


Table 3: The Impact of Import Competition and Technology on Wage Inequality: Timing Issues. (2-stage GMM)

\begin{tabular}{|c|c|c|c|c|}
\hline \multirow{4}{*}{$\begin{array}{l}\text { Independent } \\
\text { Variables }\end{array}$} & \multirow{2}{*}{\multicolumn{4}{|c|}{ Dependent Variable: }} \\
\hline & & & & \\
\hline & \multicolumn{2}{|c|}{ 1972-1990 } & \multicolumn{2}{|c|}{ 1991-2005 } \\
\hline & $\begin{array}{c}\text { Model 1 } \\
\text { All independent } \\
\text { vars. treated as } \\
\text { endogenous } \\
\end{array}$ & $\begin{array}{l}\text { Model } 2 \\
\ln S \text { and } \ln K \\
\text { treated as } \\
\text { endogenous } \\
\end{array}$ & $\begin{array}{l}\text { Model } 3 \\
\text { All independent } \\
\text { vars. treated as } \\
\text { endogenous } \\
\end{array}$ & $\begin{array}{c}\text { Model 4 } \\
\text { lnTFP and } \\
\text { lnICLWC treated } \\
\text { as endogenous } \\
\end{array}$ \\
\hline Shipments & $\begin{array}{c}0.01621 \\
(0.01886)\end{array}$ & $\begin{array}{c}0.00348 \\
(0.02415)\end{array}$ & $\begin{array}{c}-0.04928^{* * *} \\
(0.01725)\end{array}$ & $\begin{array}{c}-0.04800^{* * *} \\
(0.01694)\end{array}$ \\
\hline Capital Intensity & $\begin{array}{c}0.02609 \\
(0.02363)\end{array}$ & $\begin{array}{c}0.02830 \\
(0.02415)\end{array}$ & $\begin{array}{l}-0.02306 \\
(0.02615)\end{array}$ & $\begin{array}{c}-0.04402 \\
(0.02713)\end{array}$ \\
\hline TFP & $\begin{array}{c}0.00569 \\
(0.04887)\end{array}$ & $\begin{array}{l}0.06020^{*} \\
(0.03455)\end{array}$ & $\begin{array}{l}-0.03926 \\
(0.03817)\end{array}$ & $\begin{array}{l}-0.06937 \\
(0.04560)\end{array}$ \\
\hline $\begin{array}{l}\text { Import Competition } \\
\text { (LWCs) }\end{array}$ & $\begin{array}{l}-0.00358 \\
(0.00322)\end{array}$ & $\begin{array}{l}-0.00172 \\
(0.00145)\end{array}$ & $\begin{array}{l}0.01209 * * * \\
(0.00438)\end{array}$ & $\begin{array}{c}0.01176^{* * * *} \\
(0.00441)\end{array}$ \\
\hline Observations & 4526 & 4956 & 5528 & 5528 \\
\hline R-squared & 0.0372 & 0.0372 & 0.0406 & 0.0462 \\
\hline Root MSE & 0.1013 & 0.101 & 0.109 & 0.109 \\
\hline $\begin{array}{l}\text { Underidentification Test: } \\
\text { (Kleibergen-Paap rk } \\
\text { LM-statistic) } \\
\text { Chi-sq } p \text {-value }\end{array}$ & $\begin{array}{l}154.601 \\
(0.0000)\end{array}$ & $\begin{array}{l}248.510 \\
(0.0000)\end{array}$ & $\begin{array}{l}232.916 \\
(0.0000)\end{array}$ & $\begin{array}{l}225.897 \\
(0.0000)\end{array}$ \\
\hline $\begin{array}{l}\text { Weak Identification Test: } \\
\text { (Cragg-Donald Wald } \\
\text { F-statistic) }\end{array}$ & 163.738 & 694.781 & 373.347 & 693.682 \\
\hline $\begin{array}{l}\text { (Kleibergen-Paap rk } \\
\text { Wald } \\
\text { F-statistic) }\end{array}$ & 29.723 & 167.062 & 90.611 & 144.914 \\
\hline $\begin{array}{l}\text { Overidentification Test: } \\
\text { (Hansen J-statistic) } \\
\text { Chi-sq } p \text {-value }\end{array}$ & $\begin{array}{c}8.656 \\
(0.2783) \\
\end{array}$ & $\begin{array}{c}1.887 \\
(0.7566)\end{array}$ & $\begin{array}{c}7.576 \\
(0.4780)\end{array}$ & $\begin{array}{c}6.426 \\
(0.1690) \\
\end{array}$ \\
\hline
\end{tabular}

Notes: All variables are logged. Year fixed effects included but not shown. Robust standard errors are shown in parentheses. * indicates significant at the 0.1 level, ** indicates significant at the 0.05 level, *** indicates significant at the 0.01 level. Newey-West standard errors with a Bartlett kernel ensure estimates are robust to arbitrary serial correlation as well as heteroscedasticity. Three period lags of all independent variables were used as instruments in models 1 and 3. In model 2, where TFP and Import Competition are treated as exogenous, three period lags of Capital Intensity and Shipments were used as instruments. In model 4, where $\ln S$ and $\ln K$ are treated as exogenous, three period lags of TFP and Import Competition were employed as instruments. 
Table 4: Robustness Checks (Substituting the Computer Share of Capital Investment for Total Factor Productivity)

\begin{tabular}{|c|c|c|}
\hline \multirow[t]{2}{*}{ Independent Variables } & \multicolumn{2}{|c|}{$\begin{array}{c}\text { Dependent Variable: } \\
\text { Wage Ratio }\end{array}$} \\
\hline & $\begin{array}{c}\text { Model 1 } \\
\text { 1982-1992 }\end{array}$ & $\begin{array}{c}\text { Model 2 } \\
(1992-2005)\end{array}$ \\
\hline Shipments & $\begin{array}{c}0.02347 \\
(0.04681)\end{array}$ & $\begin{array}{l}-0.03996^{*} \\
(0.02313)\end{array}$ \\
\hline Capital Intensity & $\begin{array}{c}0.02303 \\
(0.04119)\end{array}$ & $\begin{array}{l}-0.00819 \\
(0.03065)\end{array}$ \\
\hline Computer Share of Investment & $\begin{array}{c}0.02697 * * \\
(0.01383)\end{array}$ & $\begin{array}{l}-0.00144 \\
(0.00757)\end{array}$ \\
\hline Import Competition (LWCs) & $\begin{array}{c}0.00130 \\
(0.00458) \\
\end{array}$ & $\begin{array}{c}0.02009 * * * \\
(0.00539)\end{array}$ \\
\hline Observations & 587 & 1078 \\
\hline R-squared & 0.0305 & 0.0441 \\
\hline
\end{tabular}

